\title{
Using Animal Metaphors To Create And Maintain Positive Changes In The Workforce
}

\author{
Richard Bame, University of Phoenix, USA \\ Kimberly Lowrey, University of Phoenix, USA \\ Pamela Ann Gordon, University of Phoenix, USA \\ Lili Melton, University of Phoenix, USA
}

\begin{abstract}
Twenty-first century leaders fully realize that it costs more to recruit a new employee than to manage and retain current employees. Organizations that must hire and train a new employee for a job produces added costs when replacing an employee who quits because of inappropriate workplace behaviors. Therefore, managers should never ignore inappropriate employee behavior because even loyal employees leave organizations because of uncomfortable or unsafe work environments. Managers tend to avoid the painful process of managing employee behavioral problems, much like the head burying ostrich. This qualitative historical case research study explores trends spanning the past 23 years. Data reports show increases in inappropriate employee behaviors. Presented themes use metaphors based upon animal behaviors to offer suggestions for avoiding the subsequent high costs of recruiting new employees, increased litigation costs, and injury or death caused by inappropriate behaviors in the workplace. Findings of analyzing 23 years of close to 2,000 articles found four major themes described as an animal metaphor of bullying. The majority of bullying reported fell into the horse kicker bully who practices screaming, hitting, cussing, and otherwise socially unaccepted behavior. Theme number two found $35 \%$ of bullying compares to the subtle and cunning snake. Theme number three found that 18\% of bullies compare to the howling monkey bullying. Finally, theme number four found that $16 \%$ of bullying compares to the ever-talkative parrot bully who takes credit and uses the rumor mill to bully others.
\end{abstract}

Outlier was a concern with a growing percent of top leaders classified as successful sociopaths or psychopaths. Solutions to reduce each type of bullying include stop hiring unethical employees by using a more careful analysis of traits; mandate leadership styles such as eliminating the lassiezfaire or dictatorship style; hold employees accountable for actions to stop any bullying; control the actions of managers, meetings, credit given, and the rumor mill; and keep in mind that a lack of action toward bullying is not the same as an anti-bullying policy. A high level SMACK model is presented to guide leaders on reducing workforce bullying.

Keywords: Bullying; Lassiez-Faire; Organizational Culture Mobbing; Harassment; Employee Turnover; Leadership; Psychopath; Sociopath; Leader-Member Exchange Model

\section{INTRODUCTION}

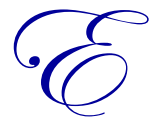

ven in the $21^{\text {st }}$ century and in the present economic conditions, the treatment of employees relates similarly to animals in the workplace setting (Sperry, 2009). Consider a hiring process of employees if a leader looked for good dogs that hunt with a passion, or well-behaved workhorses, or quickly disciplined the pack or herd with a smart smack if they stray. The leader could corral the team with a high fence knowing the dogs would form a pack for efficiency and the horses would form a herd for protection. Organizations could isolate the spiders or snakes that cost the organization profits and quickly fumigate them to preserve the 
culture. This paper employs a metaphor-based analysis of smacking the dog (employee) on the nose if he or she behaves inappropriately and rewarding the employee with a treat for good behavior.

Fortunately, some laws intervene (Kaplan, 2010); however, the laws are inadequate and human beings still suffer ill treatment like animals in the business setting. Using a metaphor related to animal behaviors, this presentation creates a model for effective elimination of inappropriate behaviors in the workforce that result in higher organizational costs and the possible escalation of workforce violence.

\section{BACKGROUND}

\section{The Ostrich Effect - Avoidance of Dealing with Workforce Bullying}

The first identification on the subject of workforce bullying in the $21^{\text {st }}$ century occurred over twenty years ago by Leymann (1990) who used the term mobbing to describe "recurring hostile and unethical occurrences in the workplace perpetuated for six months or longer by one or more individuals toward another employee" (p. 119). Bullying behaviors consist of repeated instances of querulous behavior (Zapf, 1999), spreading malicious rumors (Rayner, 1997), bullying e-mails (Baruch, 2004), physical abuse (Einarsen, 1999; Rayner, 1997), and psychological abuse (Einarsen, 1999). However, the phenomenon has evolved with international guidelines defining bullying as "behavior that disadvantages the recipient and is defined largely by the impact of the behavior - not its intention. Persistent offensive, abusive, intimidating, malicious or insulting actions or comments, as well as abuse of power or unfair penal sanctions, are all examples of behavior that leave the recipient feeling upset, threatened, humiliated or vulnerable" (Long, 2002, p. 4).

The evolution of the definition of bullying continued such that bullying currently focuses on the behavior. According to Long (2002), bullying is a behavior, not a person; "It often involves a person in authority bullying subordinates, but it may also be group behavior. Isolated managers may be bullied by their peer group or by a workforce group" (p. 5). Cooper and Schindler (2001) found bullying was more rampant in organizations with a higher percentage of autocratic, divisive, and laissez-faire management styles and lower in more democratic, participative styles.

Although few reported cases existed 30 years ago, workforce bullying has increased to amounts in 2010 responsible for a turnover of 21 to 28 million workers (Workplace Bullying Institute, 2010) to the extent of 50\% of police calls in the United States concern the workplace. Furthermore, almost half of all employees at work (47\%) suffer the effects of bullying and $71 \%$ of bullies fall into positions of supervisors or managers (Workplace Bullying Institute, 2010). Top management ignores most cases with $62 \%$ of the cases getting worse resulting in employees leaving the organization (2010). In a study by Skogstad, Einarsen, Torsheim, Aasland, and Hetland (2007) Laissezfaire leadership positively correlated with role conflict, role ambiguity, and conflicts with coworkers, which often leads to bullying.

Ignoring workforce bullying costs organizations a tremendous amount of money related to employee turnover. Leaders are well aware that the costs of recruiting a new employee far outweigh the costs of managing and retaining a current employee. The estimates of replacement hiring and training of a new employee at a salary of $\$ 50,000$ dollars averages over $\$ 75,000$ or $150 \%$ or more of the salary to replace the employee who quits to escape bullying (Solnik, 2012). These costs include training, benefits, and the initial wait time for the employee to achieve an acceptable level of productivity (Solnik, 2012). As cases of bullying litigation flow through equal employment protection laws in the United States, Fox and Stallworth (2009) estimate that "litigating bullying-related claims costs can exceed $\$ 350,000$ per case" (p. 250). Therefore, ignoring bullying-type inappropriate employee behaviors that adversely affect other employees comes with extreme costs to organizations.

While recognizing that dealing with employee bullying is painful, many managers simply avoid and run from problems, similar to the ostrich who sticks its head in the sand. The ostrich theory of ignoring bullying results in lost profits and increased new hire costs as employees leave the company (Solnik, 2012), expensive litigation from disgruntled employees, and sometimes escalated violence leading to death. For example, the United States Post office more than doubled its budget - to $\$ 641$ million - for estimated payouts for disgruntled former employee 
grievances (Reilly, 2011). If this type of cost is not enough to diminish the ostrich effect, another consideration is that "homicide is the third highest work-related cause of death in the United States" (Workforce Violence, 2012, p. 2). In 2012, "Workplace violence, in its most lethal form, is a substantial contributor to death and permanent impairment. An estimated 20 workers are murdered each week, and an additional 18,000 are assaulted. Untold numbers suffer psychological consequences from bullying, teasing, and verbal abuse" (Ditmer, 2011, p. 1). If the employee is a woman, the rate is much higher, accounting for " $42 \%$ of all deaths at work" (Workforce Violence, 2012, p. 1).

Leadership training is expensive and often the one resource organizations ignore in today's economy when companies are struggling to survive. The purpose of this article was to analyze 20 years of historical articles related to workforce bullying to determine the major types of workforce bullying and to present common solutions found as a model to help organizational leaders stop inappropriate employee bullying. The development of a model using the SMACK acronym came from the findings.

\section{METHOD}

Researchers analyzed 2,000 historical articles spanning a 23-year period as the basis for developing options to avoid and deal with inappropriate employee behaviors. Metaphors based on animal behaviors described the bully types and the SMACK model represented actions that organizations could employ to reduce or eliminate bullying. Educating leaders on the SMACK model is a cost effective way to help leaders avoid and reduce inappropriate employee bullying at all levels. The presentation of findings occurred in the form of the animal metaphor themes and the introduction of the SMACK model.

\section{FINDINGS}

\section{Theme 1: The Horse Bully - Avoid the Kickers}

A major theme of over 23 years of articles found that the majority of the articles focused on the worst horror stories with the most extreme of the bullying cases termed here as the kickers. The kickers are often employees who look good on paper with impressive resumes and experience but, when hired, lash out against others with extremely poor behavior, including yelling, retaliation, screaming in employees faces, fights, and worse. (Locander \& Luechauer, 2005) found that the kickers believe that they have to scream to get results, so behaviors focus on making noise at anyone's expense. For example, Van Gelder (2013) reported the following case during an interview with Joseph R. Weintraub, a professor of management and organizational behavior at Babson College in Wellesley, Mass:

The most outrageous example of workplace bullying occurred at a company I was asked to consult to. At the company, I encountered a senior executive who liked to talk about "cracking the whip" if people were not performing to his satisfaction.

The executive was not just talking. To play out his threat, he had a real cowboy bullwhip on his wall, which he would use from time to time and actually crack it in the hall outside his office to show his ire. Employees expressed their apprehension about even coming to work while this person was on the loose and were fearful about reporting him since he had recently been hired in a key managerial position. (p. BU8)

This example illustrates how the ostrich ignored these acts until the kicker bully HIT an employee and was fired.

The kicker bully theme featured articles presenting solutions to the kicker bully compared to selecting and buying an appropriate horse. The first most obvious step to avoiding employee inappropriate behavior is to find and hire employees who do not kick, buck, bite, or run wild. Not acquiring these types of horses in the organizational herd means many less inappropriate employee behaviors. Sorting the non-kickers from the kickers requires knowledge in how to assess. First, a non-kicker is an employee who demonstrates leadership traits based upon those identified by Collins (2006). These are inherent characteristics and not easily trainable traits, such as honesty, 
empathy, high ethical values, and trustworthiness (Collins, 2006). Uncovering these traits during the interview process is not easy; however, the resume may provide usable clues. For example Bravo, Won, and Shonk (2012) found that examining the resume to see if the candidate has volunteer experience provides evidence of the existence of a particular attribute. Reviewing the resume for service to others can provide another clue to the candidate's ethical make-up. A review of a candidate's social networking sites may provide further evidence regarding the candidate's personality (Vicknair, Elkersh, Yancey, \& Budden, 2010). According to Buller and McEvoy (1999), references become another means of valuable information. A review of the length of time the candidate has known the listed references and if the candidate presents a combination of professional and character references. When contacting a reference, the employer should ask about leadership traits of the potential employee. The more time organizational leaders spend proactively conducting the search, the easier to find potential employees possessing the required traits (Buller \& McEvoy, 1999). Referring to the analogy, the ideal horse should be calm, able to do the required job, does not run wild, will not bite, and is not feared.

In addition to solid hiring practices, solutions presented in articles focused on requiring more participative and transformational leadership styles as the primary culture for current employees. Skogstad et al. (2007) conducted a study that supported the belief that the environment of high levels of interpersonal conflicts and role stress established by laissez-faire leadership provides unlimited opportunity for the workforce bully. Ignoring managers who give no direction, providing no power to managers to make informed decisions, and lack of resources contribute to the frustration of managers who subsequently increase bullying behavior toward subordinates under their control (Skogstad et al., 2007).

In the article, Bullying and Harassment at Work (Brizzell, 2009), a key factor in preventing and dealing with bullying was that top management must be involved in creating a culture where bullying is not tolerated. To create such a culture, management should (Brizzell, 2009):

1. Develop a policy in consultation with all stakeholders. This process could include a climate survey to provide a snapshot of current attitudes and practices.

2. Implement an education and training program, supported by a realistic budget, to raise awareness and understanding and ensure that policies are implemented. This will help people understand what bullying is and is not, and encourage them to report it.

3. Implement a fair, transparent, prompt and consistent process for investigating complaints. The resolution of complaints may involve formal or informal action (p. 5).

Finally, one of the most common suggestions found within the research entails confronting the bully, which rarely gains success. "Unfortunately, this apparently straightforward and common-sense approach is more likely to enrage than to persuade the person to see reason. It will almost certainly result in an increased vindictiveness towards whoever is making the accusation" (Sweet, 2005, p. 16). Unless top management sees the bullying (Brizzell, 2009), the employee has established a target status and becomes a prime target for retaliation. This establishes the first part of the SMACK model of (S) stop hiring unethical employees and (M) mandate leadership styles.

\section{Theme 2: The Snake Bully - The Subtle Manipulating Bully}

Theme number two focused on a type of bullying that escapes the current harassment laws. Thirty-five percent of the researched articles within the last 23 years presented the subtleness of bullying. The snake weaves alternate realities and creates false perceptions of events to attain the title of master manipulator (Locander \& Luechauer, 2005). Snakes fabricate their own brand of reality by writing people and events into their version of stories and convincing others that their perception is reality (Locander \& Luechauer, 2005). Snakes prey on the desires of others by dangling the carrot before them only to pull it back at the last minute, egging on their victims to complete the next task (Locander \& Luechauer, 2005). Snakes use the phrase, "Where do you see yourself in the next five years?" to discover what motivates an individual and promise the dream in exchange for their service (Locander \& Luechauer, 2005, p. 48). They exert a heavy toll on people to maintain their façade and leave people feeling drained, used, and abused (Locander \& Luechauer, 2005). The snake seeks to be the puppet master and control people, their environment, and the perceptions of senior management (Locander \& Luechauer, 2005). 
Snakes seek to corrupt the standard view in obtaining knowledge by perception, memory, testimony, introspection, reasoning, and rational insight (Feldman, 2003). Snakes provide false perceptions, give false testimony to upper management, and therefore create a false introspect and reasoning based on deceit. Perception leads to belief, which therefore creates truth and undoes the organization like a house of cards built on the emptiness of deceit to further the snake's personal agenda. The snake focuses on people in the organization in the hopes of catching employees doing something wrong (Bame, 2013). Over time, every employee will make a mistake during his or her tenure because employees are human. The snake waits and uses the mistake to penalize the employee (Bame, 2013). Snakes report the mistake to management, cut work hours, reduce pay raises, send warning letters, and broadcast to others the mistake to alienate the target.

Highlights of a snake bully's technique occurred in the story of Dr. San Filippo. In 1977, Dr. San Filippo of the chemistry department at Rutgers University wrote a letter to the chemistry department chairman, Professor Sidney Toby, complaining about dangerous conditions in the chemistry laboratories (San Filippo v. Bongiovanni, 1994). The New Jersey Department of Health described the conditions as generally unsatisfactory. The University took no action and two years later, Dr. San Filippo went on record in response to a newspaper story of a student collapsing from noxious fumes, that undergraduate students faced subjection to a "health hazard and an absolute danger" and that "minimum safety requirements are not being met" (San Filippo v. Bongiovanni, 1994, p. 3). The department chairman, Professor Joseph Potenza, and an administrator berated Dr. San Filippo for making the comments, even though they led to the creation of an American Association of University Professors, University Safety Committee (San Filippo v. Bongiovanni, 1994). Dr. San Filippo filed grievances citing retaliation in 1981 for the chemistry department declining to recommend him for promotion to full professorship, in 1982 for promotion denial through manipulation of his promotion packet, and in 1984 for denial of a merit salary increase (San Filippo v. Bongiovanni, 1994). Dr. San Filippo testified, without contradiction, that he was criticized by administration officials for talking to the school newspaper about unsafe conditions in the laboratories, even though he was chairman of the Safety Committee at the time and was accused of being disloyal (San Filippo v. Bongiovanni, 1994). The court discovered some unsettling evidence that Dr. San Filippo's promotion packet had been surreptitiously removed and unfavorable material secretly inserted (San Filippo v. Bongiovanni, 1994). Evidence showed that someone went to extraordinary lengths to deny Dr. San Filippo professional advantage. That same kind of conduct happened to Dr. San Filippo in his merit salary award review (San Filippo v. Bongiovanni, 1994).

Bame (2013) found that "snakes handle employee reviews by giving adequate write-ups with steadily falling scores. Many times the snake will coerce friendly co-workers of a victim to avoid the victim as if the individual had the plague. The snake also undermines other managers by attempting to lessen their supervisory authority by spreading malicious rumors. Snakes often interrupt meetings to stall any headway on a project that was not his or her idea. Additionally, the snake is an expert at kissing up and kicking down, eliminating any threat to his or her positional authority." (p. 73).

The Leader-Member Exchange model (LMX) emphases on relationships developed between leaders and individual subordinates and what leaders and subordinates offer and receive in such relationships (Thompson, 2008). Thompson (2008) found that organizations must manage an employee's personal, social, and collective identities and balance them with the roles in his or her personal lives and life-changing events. Therefore, executive management must cut the head off of the snakes in an organization by facing them and using the management tools available in the forms of grievances or evaluations. Leaders of organizations need to break the spell of the snake by dismissing the false reality. The LMX exchange results in mutual trust, positive support, informal interdependencies, greater job latitude, common bonds, open communication, high degree of autonomy, satisfaction, and shared loyalty between leader and subordinate (Truckenbrodt, 2000). Finally, everyone in the organization must pay attention to the man behind the curtain and not let a false perception become the reality of the organization. This theme supports the SMACK model with (A) hold all employees accountable.

\section{Theme 3: The Howling Monkey Bully - The Scourge of Meetings}

Eighteen percent of the researched articles in the last 23 years presented bullying in the form of the howling monkey bully persona. Monkeys like to howl for the pure pleasure of hearing the noise they make and gaining attention (Locander \& Luechauer, 2005). Monkeys practice the bullying techniques of sending massive amounts of 
emails, asking the same question repeatedly in a different manner, bombarding targets with useless information, dominating meetings by asking irrelevant questions, interrupting, and even telling non-related topic stories in a failed attempt at humor (Harrison, 2004). In some cases, the howling monkey bully pays no attention to anyone else because all of his or her energy supports the howling. The howling monkey bully subscribes to the belief that he or she alone has the wisdom at the meeting. Everyone must listen to his or her prattle as the monkey howls away in an arrogant manner, scaring away any other contributors (Harrison, 2004).

Another tactic of the howling monkey materializes in the form of the Devil's Advocate (Harrison, 2004). An atmosphere of open discussion sharing numerous perspectives creates a constructive environment during meetings. Leaders should encourage constructive arguing among meeting participants to stimulate new ideas and eliminate groupthink. However, the howling monkey seeks to argue every point, even switching sides if a settlement appears close to fruition (Harrison, 2004). Additionally, the monkey may howl in a negative manner by assuming the role of the cynic. The monkey disagrees with everything suggested and simply says no, holding the meeting hostage in a sea of negativity (Harrison, 2004).

Leaders must focus on not only creating policies against monkey bullying behavior, but also following the organizational policies set up to avoid bullying and harassment. Policies are often ignored and monkey behavior tolerated (Jackson, Clare, \& Mannix, 2002). Fevre, Lewis, Robinson, and Jones (2012) agreed, finding that managers often cover up for each other when violating bullying policies. Fevre et al. (2012) found that "when receiving ill treatment from managers, employees explained that even if they did not close ranks, company policies would be applied much less diligently, and certainly without heavy-handedness" (p. 273). Senior leaders must hold managers accountable in the same way as employees, especially when bullying behavior occurs, violating company policy.

Finally, an indicator of bullying in an organization stems from the monitoring of sick leave. Perhaps a certain manager has employees taking more sick leave than the average of other managers. Numerous sick days with no disability or true sickness documented by a physician can raise a red flag that bullying may exist (Fevre, et al., 2012). Conversely, some employees may take no sick time, even when obviously ill, because of fear of losing their jobs (Fevre, et al., 2012). Tracking of sick days and searching for trends or patterns may indicate that certain managers generate more employee sick time than other managers.

Leaders must ensure the curtailing of the monkey business presented by the howling monkey. Sending massive emails, inappropriate behavior in meetings, and failure to follow and enforce bullying policies must cease in an organization. Organizations should ensure the availability of safe quiet places for employees to escape to and provide individuals a place to calm down and regroup (Jackson, et al, 2002). Panic buttons for monkey behavior out of control with coded calls to security can be a final emergency stop provided to employees (Jackson, et al, 2002). This theme supports the SMACK model with (C) control the actions of managers, meetings, credit given, and the rumor mill.

\section{Theme 4: The Parrot Bully: The Rumor Mill}

Seventeen percent of bullying researched in the last 23 years comprises theme four as the parrot or mocking bird persona (Bame, 2013). The parrot repeats everything heard as fact, including partial statements out of context. The parrot or mocking bird not only spreads rumors; they are the operator of the rumor mill. The parrot flutters around the office constantly on the lookout for new gossip and nests in the break room or mail room trying to listen in on every conversation, collecting as much meaningless information as possible. The rumor mill represents a powerful means of informal communication in an organization (Crampton, 1998). Because the rumor mill intertwines throughout an organization, rumors spread rapidly without a means to control and can cause serious harm to people and the organization (Crampton, 1998).

An example of the parrot bully is the case highlighting the career of Ms. Duncan with the Denver police force. She entered the force at a time when it was unusual for women to be police officers and she endured more than her fair share of abuse, hostility, and discrimination. She persevered until the late 1990s, until her exhausted patience led her to the court system. The following example highlights her testimony of the rumors that followed her after six different transfers (Duncan v. Manager, 2005). 
Ms. Duncan (Duncan v. Manager, 2005) alleged that a fellow officer exposed himself to her and when she registered her disgust with the officer, "he began spreading rumors that he was sleeping with her" (p. 2). Officers, after completing their shifts, would meet frequently in the parking lot to drink beer. This practice, deemed as "choir practice", was avoided by Ms. Duncan. Consequently, the officers would "accuse her of having an affair with any male officer who also happened to miss choir practice" (Duncan v. Manager, 2005, p. 3). Ms. Duncan testified that a persistent rumor that followed her to each assignment was "she had sex with her sergeant on the captain's desk" (Duncan v. Manager, 2005, p. 3). Ms. Duncan additionally testified that when her sergeant recommended her for a promotion, the captain asked "whether Duncan was giving him head and when other sergeants joined in the recommendation, the captain asked if they were all receiving sexual favors from Ms. Duncan" (Duncan v. Manager, 2005, p. 3).

A study performed by DeMare (1989) identified three primary means of communication in an organization. These were the informal rumor mill, formal organizational communications, and the leader level opinions. DeMare (1989) concluded that $70 \%$ of all communication that takes place in an organization is through the rumor mill. Conversely, $60 \%$ of leadership in an organization believed they communicated frequently with employees. Furthermore, $35 \%$ of employees thought leadership told them very little and thought the rumor mill gave them more information (DeMare, 1989).

Solutions to kill the rumor mill are simple, yet often ignored (DeMare, 1989). Kouzes and Posner (2003) presented management by walking around, which signifies managers walking around the workplace observing employees, talking to employees, and sending clear communication. Managers need to ask questions before taking action, communicate with their employees, listen to their concerns, and explain the reasoning behind directives, therefore explaining the whys of the business (Kouzes \& Posner, 2003). Peters and Waterman (1982) related that when managers get out of their offices, it enabled managers to connect with, communicate with, and relate to their employees. General Patton (n.d.) said, "Never tell people how to do things. Tell them what to do and they will surprise you with their ingenuity" (p. 1). General Patton believed in empowering his people and expected them to succeed. Leaders should observe the behavior of employees and analyze if the employee's behavior consistently meets with the organizations values and goals. Additionally, employees must receive recognition for their ingenuity and support. This theme supports the SMACK model with (C) control the actions of managers, meetings, credit given, and the rumor mill.

\section{Outlier: The Weasel - Psychopath or Sociopath}

While the outlier was not a pattern, there was more than one outlier found in the approximately 2,000 articles analyzed for bullying trends, especially noted within the last two years. Psychopaths possess the characteristics of no conscience, few emotions, and an inability to have any feelings or empathy for other people (Boddy, 2011). While a bully may not be a psychopath, he or she may have many psychopathic characteristics. A bully may usually act normally in many non-work situations. However, the extremely ambitious bully is always waiting to exploit others when opportunities arise (Namie, 2007). The Machiavellian nature of the bully is transparent when using others to advance their careers. Bullies excel at seeing and seizing opportunities to harm their targets (Namie, 2007).

Boddy (2011) found a strong positive correlation between corporate psychopathy and bullying. Boddy (2011) documented that $26 \%$ of all bullying incidents in the workplace were associated with corporate psychopaths. Body also noted corporate psychopaths represented only $1 \%$ of all employees in the workplace (Boddy, 2011). Clarke (2005) found that $2 \%$ of males are psychopathic and Stout (2005) reported that $4 \%$ of the population is sociopaths. Salekin, Trobst, and Krioukova (2001) found that $5 \%$ of a student sample displayed the same sociopathic traits. Boddy's (2011) study compared bullying done by brilliant leaders always in positions of power with sociopath theories, such as the socio-cognitive deficit theory, which centers on people lacking self-control. In each instance, identification of more than 10 common sociopathic traits existed, but with a twist - sociopaths in business were successful but not jailed (Boddy, 2011).

For a better understanding, the sociopath and psychopath bully share comparisons to the weasel. The weasel is an animal that will get what it wants; they always find a way into a seemingly secure site. The cunning 
weasel waits for that one mistake and pounces on the opportunity to destroy the entire chicken coop in one night. Just like the weasel, entire departments or organizations can be taken down by one sociopathic or psychopathic bully (Meyers \& Gilbert, 2013):

Ultimately, the sociopath typically emotionally destroys those close to him or her, but the sociopath destroys them in a way consistent with their unique approach to others: They take them out like your average person kills off characters in a video game. Those in the wake of the sociopath suffer because they have the liability sociopaths do not - actual human feelings that stem from a deep sense of social obligations to others, a moral anchor that is supposed to be part of having relationships (para. 3).

Additionally, Ishikawa, Raine, Lencz, Bihrle, and Lacasse (2001) classified the organizational weasel and the successful non-convicted sociopath:

Both unsuccessful and successful sociopaths had significantly more antisocial ( $p<<.001)$, histrionic ( $p$ s $=.002$ and .04 , respectively), narcissistic ( $p s=.01)$, borderline ( $p s=.02$ and $\leq .001$, respectively), and schizotypal traits ( $p$ s >.001), as well as a high level of criminal behaviors. Successful sociopaths demonstrated significantly better executive function than the unsuccessful sociopaths, $t(27)=2.78, p=.01, d=1.04$, and controls, $t(36)=2.51, p=$ $.017, d=.86$. Interestingly, successful sociopaths did not demonstrate typical sociopath anti-social behaviors and were able to control emotions and situations far better than previously reported (para. 12).

Furthermore, Hare, Herve, Mitchell, Cooper, and Spidel (2004) developed a subset of traits to identify organizational successful sociopaths:

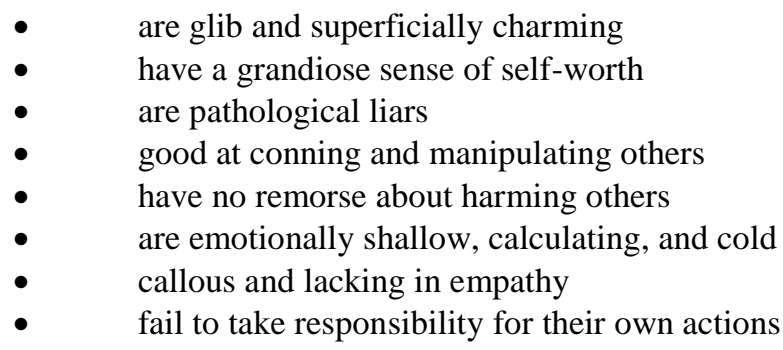

Sociopath theories indicate there are certain traits not initially obvious to the casual observer (Hare et al., 2004). Sociopaths are almost always brilliant with very high IQs that completely understand social cues and exploit this ability to their advantage (Bame, 2013). Sociopaths crave power and fear boredom so will often create chaos just for the sheer delight in creating chaos (Stout, 2005). Sociopaths are gifted and have the ability to emulate any personality after studying and planning the best approach to destroy the environment they are attacking (Stout, 2005). The organization suffers from manipulation before anyone realizes the weasel's intent. For example, Hitler had all the traits of a sociopath; he was charismatic, a good communicator, and a motivator that persuaded others to follow him regardless of the ethical repercussions. Hitler successfully manipulated Germany and the country's many resources to attempt to attain his goals of world domination.

The common thread between the weasel and the sociopath in organizations encompasses the desire to obtain their desires through the creation of chaos (Hare et al., 2004). The sociopath primarily fears boredom and, similar to the weasel, the sociopath will strategize a plan and often wait years to strike and then destroy an entire organization with one move (Stout, 2005). These traits classify the sociopathic weasel as a toxic leader in the workplace. Lipman-Blumen (2010) wrote about toxic leaders and faulted the followers as much as the leaders for tolerating such sustained behavior. Based on her study, Lipman-Blumen (2010) summarized toxic leadership as "nepotism, golden time bombs to keep them in place, using charisma to disguise reality, no new promotions of new leaders to challenge the status quo, using a divide-and-conquer mentality among subordinates, and wreaking havoc with checks and balancing systems set in place to deter subordinates" (p. 380).

Solutions to deal with the weasel are few. Hare et al. (2004) found that psychopaths even mislead experts and that identifying and dealing with a sociopath requires special care. Hare et al. (2004) suggested that it is a good 
idea to look for other victims and form a team in attempting to deal with psychopaths and sociopaths. Based on Hare et al.'s (2004) research, the psychopath or sociopath does not lack in number of victims in an organization. Hare et al. (2004) suggested that organizations should watch the types of employees who rise quickly in the organization and compare them against the sociopath traits. Hare et al. (2004) warned of the danger in engaging in a direct power struggle with a sociopath or psychopath because they will seek to inflict emotional or physical harm on those who oppose them. Both Hare et al. (2004) and Clarke (2005) advised cutting losses when dealing with sociopaths. Clarke (2005) advised leaving the organization that has sociopathic leaders because employees may not be able to prove wrongdoing has taken place. At the recruitment stage, interviewers should beware of smooth talking, charming extroverts who say all the right things and seem like ideal candidates (Clarke, 2005). A thorough screening of professional references and from their peers and subordinates can lend clues to traits (Clark, 2005). In conclusion, more research on the successful sociopath would serve organizations well before the weasel bully destroys more organizations in their pursuit of their desires. This theme further establishes the SMACK model of (S) stop hiring unethical employees and (M) mandate cultural changes.

\section{SUMMARY OF FINDINGS}

The findings of the analysis of 23 years of about 2,000 articles found four major themes described as an animal metaphor related to workforce bullying. The majority of bullying reported fell under Theme 1 of the horse kickers where screaming, hitting, cussing, and otherwise socially unacceptable behavior established the norm tolerated. Theme 2 found 35\% of bullying represented the subtle and cunning persona of the snake. Theme 3 found that $18 \%$ of bullying related to the disruptive howling monkey bully. Finally, Theme 4 found that $16 \%$ of bullying coincided with the parrot bully who takes false credit and uses the rumor mill to bully others. Additionally, the one outlier bully persona of the weasel, while not identified as a pattern, causes great alarm in the form of the sociopath and psychopath who destroys organizations in the pursuit of personal desires.

A model using the acronym SMACK represents giving leaders a jolt or reality check on workforce bullying. The SMACK model in Figure 1 illustrates solutions to how leaders can reduce each type of bullying. This approach includes stop hiring unethical employees by using a more careful analysis of traits - Mandate leadership styles, such as eliminating the lassiez-faire or dictatorship style; hold all employees accountable for actions to stop any bullying; control the actions of managers, meetings, credit given, and the rumor mill; and keep in mind that a lack of action towards bullying is not the same as an anti-bullying policy.

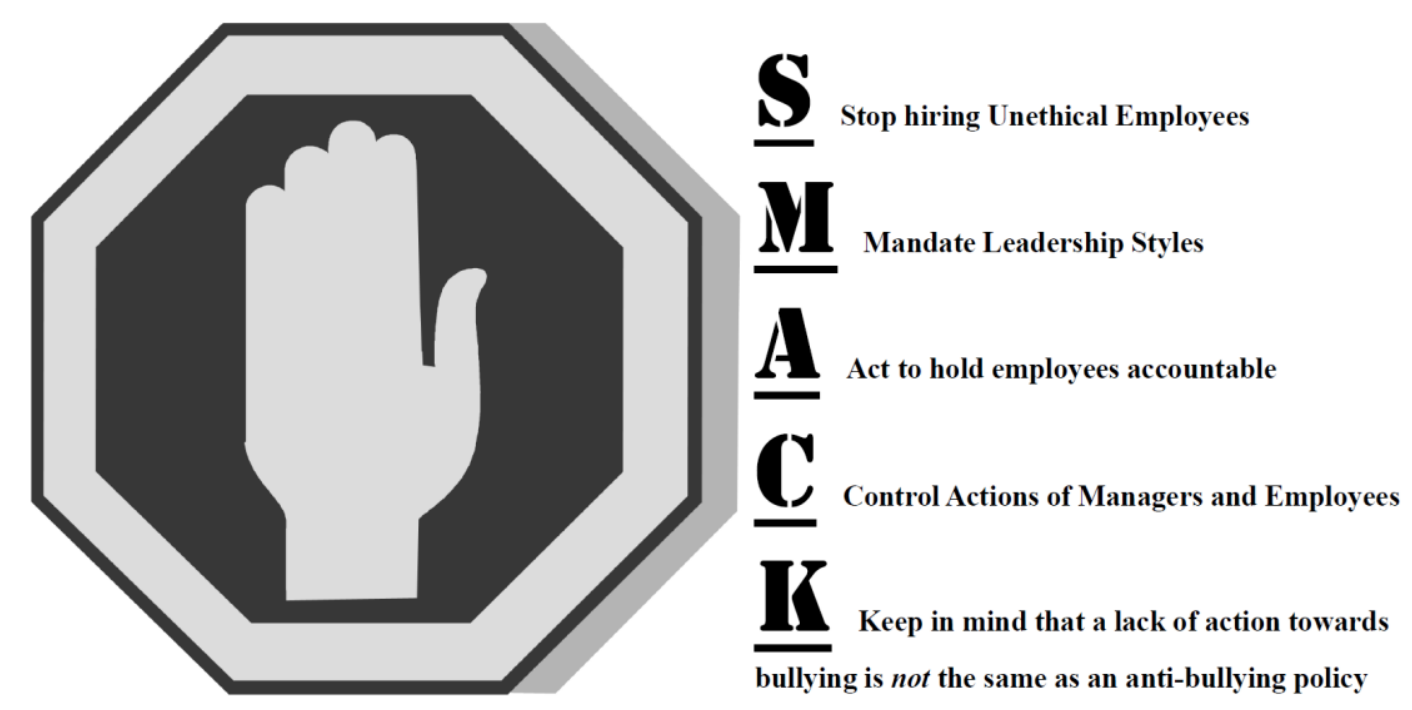

Figure 1: Smack Model 
Each letter in the word smack stands for a recommendation:

Stop hiring Unethical Employees.

$\underline{\text { M}}$ andate Leadership Styles - no Lassiez-faire or dictatorship styles.

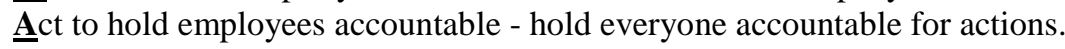

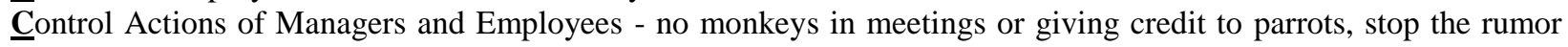
mill, and hold managers accountable.

Keep in mind that a lack of action towards bullying is not the same as an anti-bullying policy.

Unstopped bullying leads to harassment, which results in litigation, high turnover, and costs to organizations in billions of dollars. Keep monitoring sick leave and keep taking action - listen to your employees, ask for input, watch for bad behaviors, and avoid hiring kickers, snakes, parrots, weasels, and ostriches. Seek out the workhorses and loyal dogs that thrive in teams so organizations can soar like an eagle.

\section{AUTHOR INFORMATION}

Dr. Richard M. Bame earned his doctorate with the University Phoenix in the Management (Organizational Leadership) Program. He has an MBA and 21 years of leadership experience in the Navy Nuclear Power Program. He currently works for the Florida Department of Transportation as a Field Operations Manager managing asset maintenance contracts. He has 10 years of instructor experience and currently is an adjunct instructor with ITT Technical Institute teaching courses in Green Energy, Quantitative Analysis, Problem-solving, and Quality Management. His research interests are in the areas of management, leadership, and ethics. E-mail: rmbjaxfla@email.phoenix.edu (Corresponding author)

Dr. Kimberly Lowrey is a full-time research faculty in the School of Advanced Studies at the University of Phoenix for the last 14 years, researching internal projects as well as teaching quantitative and qualitative analysis. Dr. Lowrey has published on sociopaths, workforce bullying, a five-year ethnographic research study on Costa Ricans who are the second rated happiest in the world, as well as a similar study in Sicily. Dr. Lowrey has published three books and is working on a related sociopath research study on the problem of honeymoon murder increases. E-mail: kim.blum@phoenix.edu

Dr. Pamela Gordon earned her doctorate in Business Administration with a specialization in Management from Northcentral University. Her three master's degrees are in Human Resource Management, Organization and Leadership, and an MBA with a specialization in Marketing. She has 22 years of experience in the pharmaceutical industry, with 17 of those years in corporate management/leadership positions. She has more than 10 years of teaching experience and currently works for University of Phoenix fostering faculty development. Her research interests are in the areas of management, organizational behavior, marketing, and human resource management. E-mail: pam.gordon@phoenix.edu

Dr. Lili Melton earned her doctorate in Education, Teaching and Learning from Capella University. Her four master's degrees are in Curriculum and Instruction, Pupil Personnel Services, English, and Business Administration. She has 18 years of experience in education teaching kindergarten through adult education, serving as an educational mentor, and working as a school counselor. She has more than five years of teaching experience with the University of Phoenix and currently works as a full-Time faculty. Her research interests are in the areas of teaching and learning, organizational behavior, and effective qualities of female leaders. E-mail: lilimelton@email.phoenix.edu

\section{REFERENCES}

1. Bame, R. (2013). A Historical Single-Case Study On Workplace Bullying, Unpublished but approved doctoral dissertation, University of Phoenix.

2. Baruch, Y. (2004). Bullying via e-mail. Information \& Management, 42(2), 361-371.

3. Boddy, C. (2011). Corporate psychopaths, bullying and unfair supervision in the workplace. Journal of Business Ethics, 100(3), 367-379. doi:10.1007/s10551-010-689-5. 
4. Bravo, G., Won, D., \& Shonk, D. J. (2012). Entry-level employment in intercollegiate athletic departments: Non-readily observables and readily observable attributes of job candidates. Journal of Sport

Administration \& Supervision, 4(1), 63.

5. Brizzell, A. (2009). Bullying and harassment at work. Irish Medical Times, 43(4), 30. Retrieved from http://search.proquest.com/docview/227302382?accountid=458

6. Buller, P. F., McEvoy, G. M. (1999). Creating and sustaining ethical capability in the multi-national corporation, Journal of World Business, 34(4), 326-343, doi:10.1016/S1090-9516(99)00022-X.

7. Clarke, J. (2005). Working with monsters: How to identify and protect yourself from the workplace psychopath, Sydney, AU: Random House.

8. Collins, D. (2006). Five levees for improving ethical performance. Strategic Finance, 88(1), 19-20, 61. Retrieved from http://search.proquest.com/docview/229789853?accountid=458

9. Cooper, D. R., \& Schindler, P. S. (2001). Business research methods (7th ed.). New York, NY: McGrawHill.

10. Crampton, S. M. (1998). The informal communication network: Factors influencing grapevine activity. Public Personnel Management, 27(4), 569.

11. DeMare, G. (1989). Communicating: The key to establishing good working relationships. Price Waterhouse Review, 33, 30-37.

12. Ditmer, D. (2011). Violence in the house of healing: Recognition \& response to violence in health care. Forensic Examiner, 20(1), 15-29. Retrieved from http://search.proquest.com/docview/1033346361? accountid=458

13. Duncan v. Manager, Dept. of Safety, 397 F. 3d 1300 - Court of Appeals, 10th Circuit 2005.

14. Einarsen, S. (1999). The nature and causes of bullying at work. International Journal of Manpower, 20, 1627.

15. Feldman, R. (2003). Epistemology. Upper Saddle River, NJ: Prentice Hall.

16. Fevre, R., Lewis, D., Robinson, A., \& Jones, T. (2012). Insight into ill-treatment in the workplace: Patterns, causes, and solutions. Contemporary Readings in Law \& Social Justice, 4(2), 245-277.

17. Fox S., \& Stallworth L.E. (2009). Building a framework for two internal organizational Approaches to resolving and preventing workplace bullying: Alternative dispute Resolution and training. Consulting Psychology Journal, 61(3), pp. 220-241.

18. George S. Patton quotes. (n.d.). Retrieved from http://www.brainyquote.com/quotes/authors/g/george_s_patton_2.html

19. Hare, R., Herve, H.F., Mitchell, D., Cooper, B.S., \& Spidel, A. (2004). Psychopathy and unlawful confinement: an examination of perpetrator and event characteristics, Canadian Journal of Behavioural Science, 36(2), 137-145.

20. Harrison, C. (2004). Meeting monsters. Executive Excellence, 21(1), 18.

21. Ishikawa, S. S., Raine, A., Lencz, T., Bihrle, S., \& Lacasse, L. (2001). Autonomic stress reactivity and executive functions in successful and unsuccessful criminal psychopaths from the community. The Journal of Abnormal Psychology, 110(3). 423-432.

22. Jackson, D., Clare, J., \& Mannix, J. (2002). Who would want to be a nurse? Violence in the workplace - a factor in recruitment and retention. Journal of Nursing Management, 10(1), 13-20. doi:10.1046/j.09660429.2001.00262.x.

23. Kaplan, J. F. (2010). Help is on the way: A recent case sheds light on workplace bullying. Houston Law Review, 47(1), 141-173.

24. Kouzes, J. M., \& Posner, B. Z. (2003). The leadership challenge (3rd ed.). San Francisco, CA: JosseyBass.

25. Leymann, H. (1990). Mobbing and psychological terror at workplaces. Violence \& Victims, 5(2), 119-126.

26. Lipman-Blumen, J. (2010). Toxic leaders: They're plentiful. In G. R. Hickman (Ed.) Leading organizations: Perspectives for a new era, pp. 377-390. Thousand Oaks, CA: Sage Publications, Inc.

27. Locander, W. B. \& Luechauer, D. L. (2005). Don't be a bully. Marketing Management, 14(4), 48-50.

28. Long, J. A. (2002). Taking the BULLY by the horns. The Safety \& Health Practitioner, 20(2), 30-33.

29. Meyers, S., \& Gilbert, K. (2013). Understanding the sociopath: Cause, motivation, relationship: the sociopath remains largely misunderstood [Blog]. In S. Meyers \& K. Gilbert, Insight is 20/20: Exploring the pervasive, and unperceived, patterns that govern our lives. Psychology Today. 
30. Namie, G. (2007). The challenge of workplace bullying. Employment Relations Today (Wiley), 34(2), 4351. doi:10.1002/ert.20151.

31. Peters, T. J., \& Waterman Jr. R. H. (1982) In search of excellence: Lessons from America's best run companies. New York, NY: Warner Books Inc.

32. Rayner, C. (1997). The incidence of workplace bullying. Journal of Community and Applied Social Psychology, 7(3), 199-208.

33. Reilly, S (2011). \$641 million: The costs of disgruntled employees. Federal Times. From http://www.federaltimes.com/article/20111023/DEPARTMENTS02/110230303/-641-million-pricedisgruntled-employees

34. Salekin, R.T., Trobst, K.K., \& Krioukova, M. (2001). Construct validity of psychopathy in a community sample: A nomological net approach. Journal of Personality Disorders, 15(5), 425-441.

35. San Filippo v. Bongiovanni, 30 F. 3d 424 - Court of Appeals, 3rd Circuit 1994.

36. Skogstad, A., Einarsen, S., Torsheim, T., Aasland, M., \& Hetland, H. (2007). The destructiveness of laissez-faire leadership behavior. Journal of Occupational Health Psychology, 12(1), 80-92. doi:10.1037/1076-8998.12.1.80.

37. Solnik, C. (2012). Surviving employee turnover. Long Island Business News, Retrieved from http://search.proquest.com/docview/993795551?accountid=458

38. Sperry, L. (2009). Workplace mobbing and bullying: A consulting psychology perspective and overview. Consulting Psychology Journal: Practice and Research, 61(3), 165-168. doi:10.1037/a0016936.

39. Stout, M. (2005). The ice people: Living among us are people with no conscience, no emotions and no conception of love: Welcome to the chilling world of the sociopath. Psychology Today, January/February, 72-76.

40. Sweet, M. (2005). Beating bullying. Australian Nursing Journal, 12(9), 16-9. Retrieved from http://search.proquest.com/docview/236575719?accountid=458

41. Thompson, L. L. (2008). Making the team (3rd ed.). Upper Saddle River, NJ: Pearson Prentice Hall.

42. Truckenbrodt, Y. B. (2000). The relationship between leader-member exchange and commitment and organizational citizenship behavior. Acquisition Review Quarterly, 3, 233-244.

43. Van Gelder, L. (2013, November 23). Foiling the office bully (with sand in your face). New York Times, p. BU8.

44. Vicknair, J., Elkersh, D., Yancey, K., \& Budden, M. C. (2010). The use of social networking websites as a recruiting tool for employers. American Journal of Business Education, 3(11), 7-12.

45. Workplace Bullying Institute. (2010). Results of the 2010 WBI U.S. Workplace Survey. Retrieved from http://www.workplacebullying.org/docs/WBIsurvey2010.pdf

46. Workforce Violence (2012). Human Resources at WOI. From http://www.whoi.edu/page/live.do?pid=22079

47. Zapf, D. (1999). Organizational, work group related and personal causes of mobbing/bullying at work. International Journal of Manpower, 20, 70-85. 